\title{
Ecological and Financial Effects of Coal-Fired Boiler Replacement with Alternative Fuels
}

\author{
Danuta Proszak ${ }^{1 *}$, Sławimir Rabczak¹, Elżbieta Rybak-Wilusz' \\ 1 Faculty of Civil and Environmental Engineering and Architecture, Rzeszow University of Technology, Rzeszow \\ 35-959, Powstańców Warszawy 12, Poland \\ * Corresponding author's e-mail: dproszak@prz.edu.pl
}

\begin{abstract}
Nowadays, much attention is paid to the elimination of heat sources poisoning our environment. The air pollution is the most dangerous form of pollution of the environment, due to its direct impact on all living organisms, coverage of large areas and easy movement of pollutants. Therefore, air protection is one of the priority directions of each voivodeship. Hence, many programmes are being developed to promote the replacement of the old heating devices with the new ones and the installation of renewable energy conversion devices. There is no doubt that the equipment which emits the most harmful compounds into the atmosphere includes the old boilers fired with coal, wood or wood chips. In winter, chimneys with black circular smoke are a frequent sight. This problem can only be solved by connecting houses to the public heating network or by removing the old stoves. In this publication, an analysis of the profitability of boiler replacement with coal was carried out in terms of the material and environmental benefits. It is proposed to replace this boiler with a pellet boiler, an eco-pea boiler and a gas condensing boiler. The boilers were selected on the basis of the calculated thermal output, which is equal to $18.56 \mathrm{~kW}$.
\end{abstract}

Keywords: alternative fuels, coal-fired boiler, biomass

\section{INTRODUCTION}

The air pollution is the most dangerous form of environmental pollution as it directly affects all living organisms, covers large areas and is easy to move. Therefore, air protection is a priority for each province. A large number of programmes have been created to encourage the exchange of the old heating devices to the new ones and to assemble the devices for renewable energy conversion.

Undoubtedly, the devices which emit the largest amounts of harmful compounds to the atmosphere include the old boilers burning coal, wood and woodchips [Proszak-Miasik, Rabczak, 2019]. Chimneys with black billowy smoke coming out of it can be frequently observed in winter. Such a problem may only be solved by connecting the houses to the public heat distribution system or by liquidating the old boilers.
Obsolete coal boilers may be replaced by the coal boilers with class 5 emission parameters; an exchange of a furnace to a gas boiler, oil boiler, gasifying boiler, class 5 pellet boiler or an ecopea coal boiler, which emit scanty amounts of dusts is also a very good idea. The systems using alternative energy, supporting the heat and electricity production, such as solar collectors, solar cells, wind turbines and heat pumps, are also becoming increasingly popular. Below, an exchange of an old boiler to a boiler using alternative fuel, such as eco-pea coal, gas and pellets, were suggested.

\section{DESIGN ASSUMPTIONS}

The building for which the ecological and economical analysis was made is a creche, where the existing central heating coal boiler was exchanged to a boiler using alternative fuel (eco-pea coal, 
pellets and gas). This is a detached, one-storey building with an attic which has been partially made into rooms and which is not heated. The heated area is $337 \mathrm{~m}^{2}$ (capacity: $1060 \mathrm{~m}^{3}$ ). On the first floor, there are 21 rooms, including two unheated rooms which are not heated: a storeroom and the room for keeping cleaning products. The building was erected using a traditional brick technology with external walls made of $25 \mathrm{~cm}$ thick ceramic hollow bricks and was insulated with $15 \mathrm{~cm}$ thick EPS 100 polystyrene foam. The ceiling under the non-heated attic was also isolated with mineral wool.

The building is located in the third climatic zone, according to PN - EN 12831 2006; therefore, the design external temperature $\theta \mathrm{e}=-20^{\circ} \mathrm{C}$ was taken for calculations, and the design average annual external temperature is $\theta \mathrm{m}, \mathrm{e}=7.6^{\circ} \mathrm{C}$ [PN-EN 12831:2006].

The existing central heating system operates as a branched distribution system to which the heating medium is supplied from an individual boiler located in the building. The medium temperature on the supply and return lines is $75 / 55^{\circ} \mathrm{C}$. The heating panels fed from the bottom are installed. Such heaters fulfil the requirements described, inter alia, in the Regulation of the Minister of Infrastructure of 12 April 2002 [Rozporządzenie Ministra Infrastruktury, 2002] and in the Regulation of the Minister of Labour and Social Policy of 10 July 2014 concerning building and sanitary requirements for facilities in which creches or children's club are held [Rozporządzenie Ministra Pracy i Polityki Społecznej, 2014]. Special heat receivers, which facilitate cleaning and are equipped with covers for safety reasons, are required in a building intended for children's use. Heating panels with smooth surfaces and without side covers or convection elements were used.

A coal boiler (KW) constitutes a heat source in the original version. This analysis is aimed at showing the effects concerning the financial and ecological benefits which can be obtained by replacing such a boiler with a boiler burning a different type of fuel. The selected boilers have design thermal power of $18.56 \mathrm{~kW}$. Particular options include a pellet boiler (KP) with a power rating of $20 \mathrm{~kW}$, an eco-pea coal boiler (KEG) with a power rating of $20 \mathrm{~kW}$ and a gas condensing boiler (KGK) with a power rating of $24 \mathrm{~kW}$.

\section{ECONOMIC ANALYSIS OF INVESTMENT}

\section{System investment costs}

The price calculations were conducterd by using the price lists of devices and materials from the producers and distributors. The equipment for the given systems was assumed according to the technological requirements. The adjustment of the chimney to the new boiler room was also included in the assessment. The outlays were assumed on the basis of "Set of unit price indicators from general, residential and industrial construction industries".

In the building in which the boiler room is to be modernised, there is a gas connection so the following costs can be omitted: fee for the issuance of technicalconditions for gas demand, fee for gas connection design, geodetic fee, fee for gas connection acceptance and material costs.

Table 1 shows the cost of modernizing the boiler room for the individual options

\section{Operational costs}

The operational costs include the annual demand for fuel, maintenance costs and, for boilers with feeders, costs of operating the boiler.

Table 1. Boiler room modernisation costs

\begin{tabular}{|l|c|c|c|}
\hline \multicolumn{1}{|c|}{ Name } & Eco-pea coal, PLN & Pellets, PLN & Natural gas, PLN \\
\hline Materials [M] & $22,075.32$ & $20,474.27$ & $22,091.40$ \\
\hline Labour [R] = 20\% [M] & $4,415.06$ & $4,094.85$ & $3,418.28$ \\
\hline Indirect costs [Kp] = 70\% [R] & $3,090.54$ & $2,866.40$ & $1,767.31$ \\
\hline Purchase cost [Kz] = 8\% [M] & $1,766.03$ & $1,637.94$ & 961.42 \\
\hline Profit [Z]=12.8 \% [R and Kp] & 960.72 & 891.04 & $1,104.57$ \\
\hline Disassembly cost [Pd] = 25\% [R] & $1,103.77$ & $33,435.78$ \\
\hline Total cost & $33,411.44$ & $30,988.22$ & 200.00 \\
\hline Start-up of boiler of up to 50 kW & 500.00 & 500.00 & $31,488.22$ \\
\hline Total costs including maintenance & $33,911.44$ & & \\
\hline
\end{tabular}




\section{Annual demand for fuel}

Table 2 shows the parameters of fuels according to the design. A proper quality fuel is an important element determining the ecological effect and efficiency of boiler heat production. The fuel prices depend on producers and vary greatly but the application of cheaper, low-quality fuel may result in the necessity to conduct more frequent boiler maintenance inspections due to the fact that the boilers were designed for better quality fuel.

The annual consumption of gas is $2891.18 \mathrm{~m}^{3} / \mathrm{g}$ so the building has been qualified as for clients from the W-3.6 tariff group, methane-rich gas. The prices of particular components included in the final value were determined on the basis of a price list available at the website of Polska Spółka Gazownictwa [5].

When analysing the consumption of fuel under the designed conditions, the annual demand for fuel in the existing boiler room was $6726.92 \mathrm{~kg} /$ year, which gave rise to costs of PLN 4182.26. Such a cost was incurred when using fuel with a calorific value of $22.00 \mathrm{MJ} / \mathrm{kg}$ and boiler efficiency of $80 \%$. However, is should be remembered that the fuel efficiency decreases as the boiler becomes worn out. While comparing the unit cost of generating $1 \mathrm{kWh}$, the old system gave rise to the lowest cost. Pellet and natural gas boilers give rise to almost twice higher costs of producing $1 \mathrm{kWh}$. Figure 1 shows the unit cost of producing fuel.

Figure 2 shows the annual cost of fuel purchase on the basis of the computing demand for fuel and purchase cost. On that basis, it may be noted that in spite of the higher pellet and natural gas boiler efficiency, the boilers will require investing 1.5 -fold more money on the purchase of fuel annually when the owner will decide to have a gas boiler system and 2/3 more money when the owner will select a pellet boiler. Higher boiler efficiencies translate, among others, into the annual demand for fuel. The downward trend is observed but the price of the carrier itself is higher.

\section{Operating Costs}

Considering the options with solid fuel boilers, the everyday operating costs should be taken into account. These include checking and topping up fuel, verifying the amount of ash as well as removing it and cleaning the exchanger chamber every $2-5$ days. Such actions in the building in question will be taken by a technician employed to perform repairs in the buildings. It is assumed that the annual operating cost will be PLN 1500.

\section{Maintenance costs}

The next factor, which should be taken into consideration while determining the operational costs, includes the maintenance costs. Maintenance inspections are recommended by producers at least once a year and they are required to have a warranty. During the annual inspection an authorized maintenance technician checks the burner, automation system, programmer settings, whether the device operates properly in general and whether the flues and the exchanger are passable. Additionally, the chimney sweeping services for the existing boiler were included in the cost of annual inspections.

Summing up the annual operational costs (tab. 2), they are about 5900 PLN for a coal boiler, 6000 PLN for an eco-pea coal boiler, 9300 PLN for a pellet boiler and 6500 PLN for a condensing boiler.

Table 2. Fuel properties - demand for fuel

\begin{tabular}{|c|c|c|c|c|c|}
\hline \multirow[b]{2}{*}{ Parameters } & \multicolumn{5}{|c|}{ Type of boiler and heating system } \\
\hline & Unit & Coal boiler & Eco-pea coal boiler & Pellet boiler & $\begin{array}{c}\text { Condensing } \\
\text { boiler }\end{array}$ \\
\hline Efficiency & $\%$ & 80 & 94 & 93 & 105 \\
\hline Type of fuel & & Coal (nut) & Eco-pea coal & Pellets & Natural gas \\
\hline Calorific value fuels & $\mathrm{MJ} / \mathrm{kg}, \mathrm{MJ} / \mathrm{m}^{3}$ & 22.00 & 28.50 & 18.50 & 39 \\
\hline Ash content & $\%$ & 12.00 & 2.50 & 0.40 & - \\
\hline Sulphur content & $\%$ & 1.60 & 0.30 & 0.01 & 0.2 \\
\hline Humidity content & $\%$ & 20.00 & 10.60 & 8.00 & - \\
\hline Annual Demand for Heat & $\mathrm{kWh} / \mathrm{a}$ & 41108.97 & 34986.36 & 35362.55 & 31321.12 \\
\hline Annual Demand for Fuel & $\mathrm{kg} / \mathrm{a}, \mathrm{m}^{3} / \mathrm{a}$ & 6726.92 & 4419.33 & 6881.36 & 2891.18 \\
\hline Fuel price & $\mathrm{PLN} / \mathrm{t}, \mathrm{PLN} / \mathrm{m}^{3}$ & 621.72 & 949.00 & 1085.00 & - \\
\hline
\end{tabular}




\section{DETERMINATION OF EMISSIONS TO AIR}

The emissions of the following pollutants were assessed: $\mathrm{NO}_{\mathrm{x}}$ - nitric oxides, $\mathrm{CO}$ - carbon monoxide, $\mathrm{SO}_{2}-$ sulphur dioxide, PM2.5 and PM10 - particulate matter, B(a)P - benzopyrene. The values of such pollutants were assessed by an indicative method on the basis of the power of the heating device [Nowak and Bukowska, 2017]

In order to assess the emissions of $\mathrm{SO}_{2}, \mathrm{NO}_{2}$ $\mathrm{CO}$, particulate matter and benzopyrene to the atmosphere, the following relationship was applied [Janka, 2014]:

$$
E=B_{a} \cdot w\left[\frac{\mathrm{kg}}{a}\right]
$$

where: $E$ - emission of pollutants, $\mathrm{kg} / \mathrm{h}$,

$B_{a}$ - consumtion of fuel fir central heating, GJ/a

$w$ - emission factor, $\mathrm{kg} / \mathrm{GJ}$.

The emission factor of $\mathrm{SO}_{2}, \mathrm{NO}_{2} \mathrm{CO}$ and benzopyrene was assumed on the basis of a document of the European Environment Agency [6].
In order to determine the value of the $\mathrm{CO}_{2}$ emission, the methodology applied in calculating the energy performance of the building was described in the Regulation of the Minister of Infrastructure and Development concerning methodology of determining energy performance of buildings and parts of buildings, and power performance certificates of 27 February 2015 (J.L no 376 of 2015) [Rozporządzenie Ministra Pracy i Polityki Społecznej, 2014]. Thus, it was assumed that the value of the emission factor of $\mathrm{CO}_{2}$, depending on the type of burnt fuel is:

- zero for renewable energy (in the case of local production of energy in the building): solar energy, wind energy, geothermal energy, biomass and biogas.

- as indicated by the producer or supplier of the energy carrier or the energy.

If no such data is available, and in other cases, it is assumed that the value of the emission factor of $\mathrm{CO}_{2}$ is as from the year of the issue of the certificate of the National Centre for Emissions Management (KOBiZE) [Krajowy

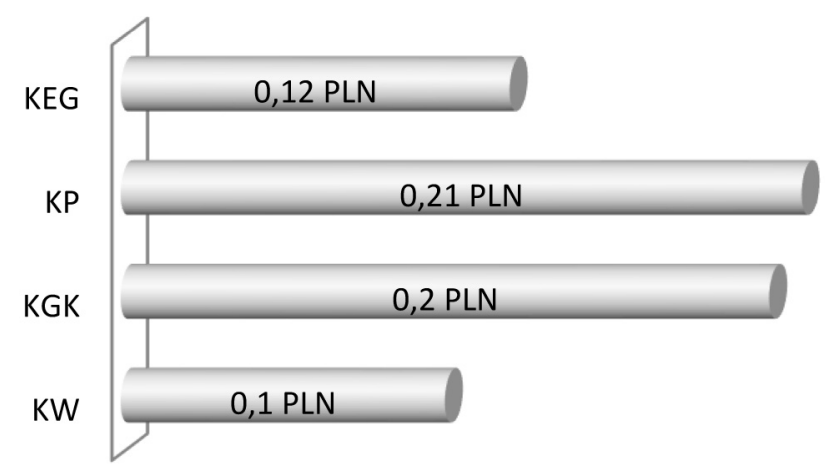

Figure 1. Cost of producing $1 \mathrm{kWh}$ of heat by suggested heat sources

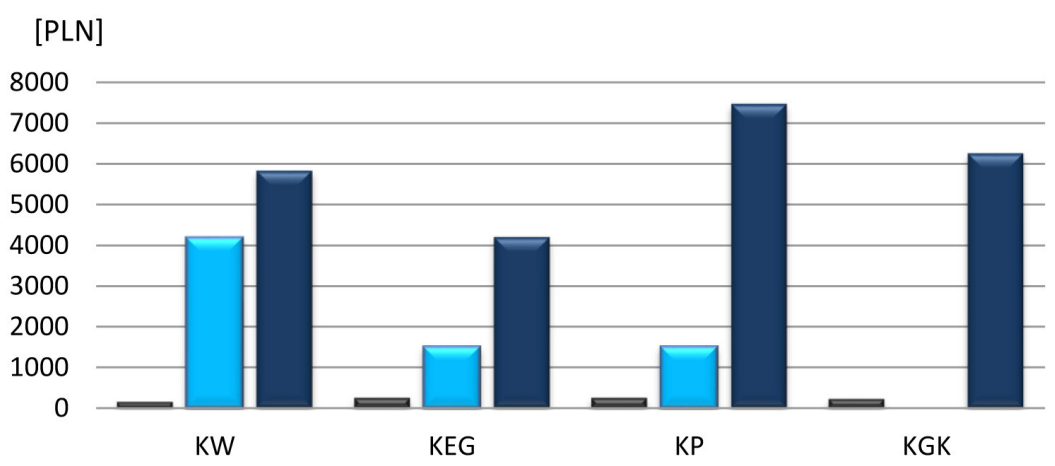

annual inspection of boilers up to $50 \mathrm{~kW}$.

Figure 2. Boiler annual operational costs 
Ośrodek Bilansowania i Zarządzania Emisjami, 2019 ], according to Article 3(2)(8) of the Act of 17 July 2009 on the system of managing emissions of greenhouse gases and other substances (J.L. no 1107 of 2013 and no 1101 of 2014) and it is calculated from the following relationship:

$$
E_{\mathrm{CO}_{2}}=36 \cdot 10^{-7} \cdot B_{a} \cdot w\left[\frac{\mathrm{kg}}{a}\right]
$$

where: $B_{o}$ - consumption of fuel for central heating needs, GJ/a, $w$ - emission factor, $\mathrm{kg} / \mathrm{GJ}$.

This analysis takes into account the annual emissions of pollutants including the amount of burnt fuel. The emissions were assessed with an indicative method on the basis of the heating device power and demand for energy. The results were presented in Table 3. Figures 3-6 show the annual emissions of $\mathrm{NO}_{\mathrm{x}}, \mathrm{SO}_{2}$, particulate matter, $\mathrm{CO}$, and $\mathrm{CO}_{2}$ to the atmosphere.

\section{CONCLUSION}

The computing cost of fuel purchase shows that the modernised boiler room gives rise to the lowest annual operational costs. Taking into account the economic aspects alone, the boiler room modernization is not justified. However, the exchange is forced due to the legal changes concerning the emissions of pollutants to the atmosphere and the

Table 3. Comparison of emissions of pollutants to air

\begin{tabular}{|c|c|c|c|c|c|}
\hline \multirow[b]{2}{*}{ Parameter } & \multirow[b]{2}{*}{ Compound } & \multicolumn{4}{|c|}{ Type of boiler and heating system } \\
\hline & & Coal boiler (KW) & $\begin{array}{l}\text { Eco-pea coal boiler } \\
\text { (KEG) }\end{array}$ & Pellet boiler (KP) & $\begin{array}{c}\text { Condensing boiler } \\
\text { (KGK) }\end{array}$ \\
\hline \multirow{7}{*}{$\begin{array}{l}\text { Emissions per } \\
\text { unit of burnt fuel } \\
{\left[\mathrm{kg} / \mathrm{m}^{3}\right]}\end{array}$} & $\mathrm{NO}_{\mathrm{x}}$ & 3.48 & 4.7 & 1.68 & 1.95 \\
\hline & $\mathrm{SO}_{2}$ & 19.8 & 12.8 & 0.2 & 0.02 \\
\hline & PM 2.5 dust & 5.03 & 2.05 & 0.61 & 0.02 \\
\hline & PM 10 dust & 5.63 & 2.3 & 0.63 & 0.02 \\
\hline & Benzopyrene & 0.0000059 & 0.0000000023 & 0.00000019 & - \\
\hline & $\mathrm{CO}$ & 44 & 8.6 & 4.1 & 1.95 \\
\hline & $\mathrm{CO}_{2}$ & 2083.4 & 2778.8 & - & 2166 \\
\hline
\end{tabular}

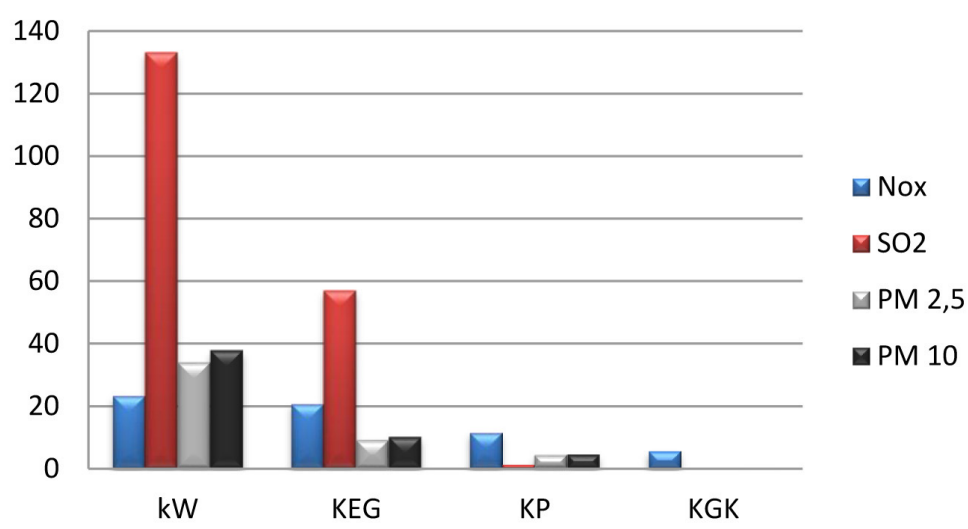

Figure 3. Annual emissions of $\mathrm{Ox}, \mathrm{SO}_{2}, \mathrm{PM} 2.5, \mathrm{PM} 10$ to the atmosphere

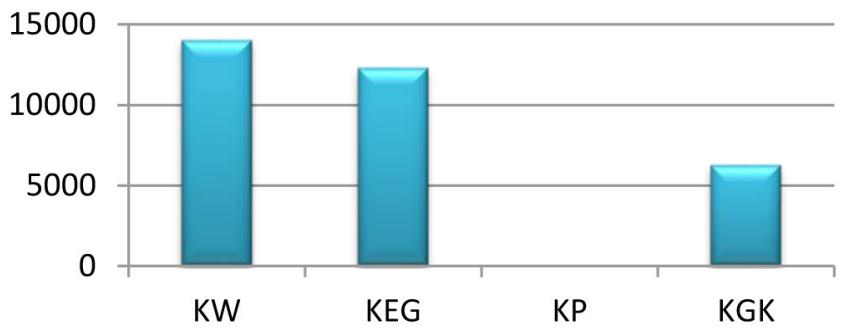

Figure 4. Annual emission of $\mathrm{CO}_{2}$ to the atmospher 


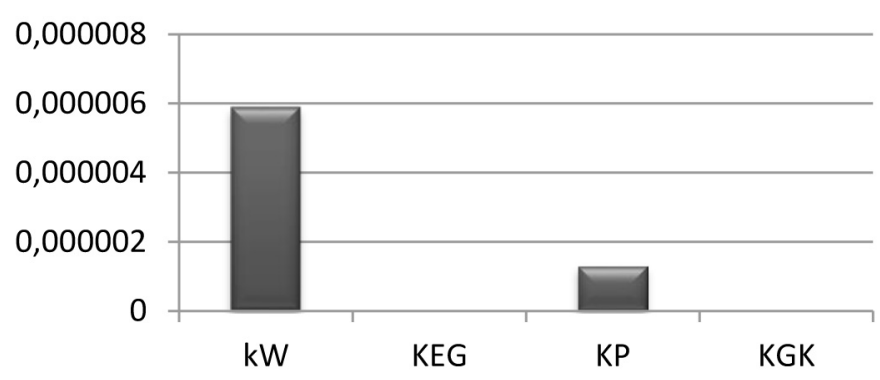

Figure 5. Annual emission of benzopyrene to the atmosphere

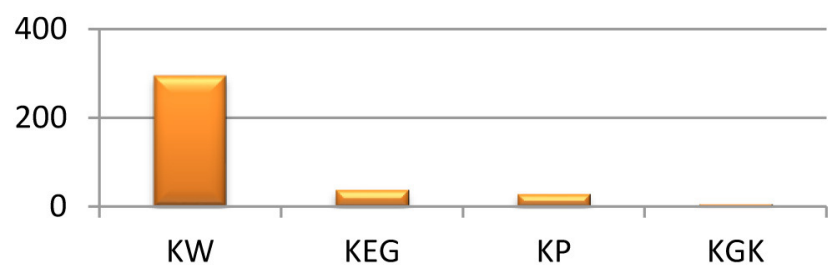

Figure 6. Annual emission of $\mathrm{CO}$ to the atmosphere

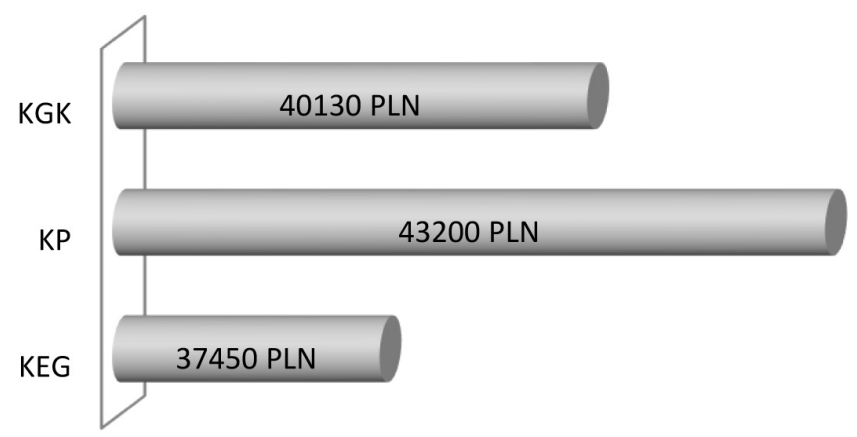

Figure 7. Total cost of modernisation

obligation to have a proper class boiler. The ecopea coal boiler option achieves the most similar annual operational cost. However, it should be remembered that such boilers compared to gas fuel boiler require constant operation including cleaning chambers and topping up fuel. While analysing the results, it may be noted that under the computing conditions, the coal boiler has the largest annual demand for heat and fuel, taking into account the boiler efficiency. However, in this option, the unit price of fuel for the production of $1 \mathrm{kWh}$ of heat is lowest out of all the options. The highest investment and operational costs will be incurred by building owners when the pellet option is selected. When using fuel of the quality described in the design, the annual demand for heat is at a similar level as in the case of coal but the fuel price is higher. While analysing the economical aspect alone, the eco-pea coal boiler option is a justified choice, but when taking into account the ease of use as a factor important in a public building, the natural gas boiler option is worth considering. Figure 7 displays the total costs which the owner will have to incur in the first year of boiler room modernisation connected with the investment and operational costs.

The largest amount of pollutants to the atmosphere is emitted by solid fuel boilers, especially coal boilers. The emission of suspended particulate matter and bensopyrene looks most favourably in the case of using a gas boiler but only the exchange of the coal boiler to an eco-pea coal boiler results in less than half the emission. Taking into account the ecological aspect when modernising the boiler room, it should be stated that using gas for heating the building is the most favourable solution. High results of pollution reduction may be also observed when using the pellet boiler, thus placing the pellet boiler second 
as an option which is most friendly for the environment, just after the gas boiler.

While analysing the ecological aspect, the emission of pollutants will be reduced most when the gas boiler is used. Taking into account only types of fuel when thinking about emissions, all options show a positive result of boiler room modernisation. However, when the factor of annual amounts of burnt fuel is considered as well, lower reduction of pollutants may be observed. The emissions of the examined pollutants show a trace emission compared to the modernised boiler room. The only indicator which shows a higher value is the indicator of $\mathrm{CO}_{2}$ emission per unit of burnt fuel. The $\mathrm{CO}_{2}$ emission concerning the coal boiler is higher by $33.40 \%$ for the eco-pea coal boiler and by $4.00 \%$ for the gas boiler room. The least favourable option resulting in lower emissions of pollutants is the eco-pea coal option. In this case, a higher emission per unit of burnt fuel may be observed for such pollutants as $\mathrm{NO}_{\mathrm{x}}$ and $\mathrm{CO}_{2}$. The emission factors for suspended particulate matter and bensopyrene are the most favourable in the case of using the condensing gas boiler and other boilers fed automatically. The limitation of emissions and the increase in the level of comfort of using the device make the gas fuel boiler option most optimal. The necessity to store fuel material and labour intensity connected with heating the building with solid fuel weigh in favour of the gas heating option.

\section{REFERENCES}

1. http://instal-energia.pl/kotly-na-pellet/, on-line 05.05.2019 r.

2. http://www.blekitnywegiel.pl/pl/blekitny-wegiel, on-line 05.05.2019 r.

3. Janka R., 2014, Zanieczyszczenia pyłowe i gazowe. Podstawy obliczenia i sterowania poziomem emisji, Wydawnictwo naukowe PWN, Warszawa 2014.

4. Krajowy Ośrodek Bilansowania i Zarządzania Emisjami, https://www.kobize.pl

5. Nowak K., Bukowska M., Proszak-Miąsik D. and Rabczak S. 2017. Emission of air pollutants in the hot water production. IOP Conference Series: Materials Science and Engineering, 245.

6. PN-EN 12831:2006. Instalacje ogrzewcze w budynkach. Metoda obliczania projektowanego obciążenia cieplnego.

7. Proszak-Miasik D., Rabczak S., 2019, The use of forest waste in the energy sector, IOP Conference Series: Materials Science and Engineering, 603052092.

8. Rozporządzenie Ministra Infrastruktury z dnia 12 kwietnia 2002 r. w sprawie warunków technicznych, jakim powinny odpowiadać budynki i ich usytuowanie (Dz.U. z 2002 r. Nr 75, poz. 690).

9. Rozporządzenie Ministra Pracy i Polityki Społecznej z dnia 10 lipca 2014 r. w sprawie wymagań lokalowych i sanitarnych, jakie musi spełniać lokal, w którym ma być prowadzony żłobek lub klub dziecięce (Dz.U. z 2014 r. poz. 925). 